ENVIRONMENTAL RESTORATION PROGRAM

\section{Waste Management Plan for the Removal Action at the Former YS-860 Firing Ranges, Oak Ridge Y-12 Plant, Oak Ridge, Tennessee}
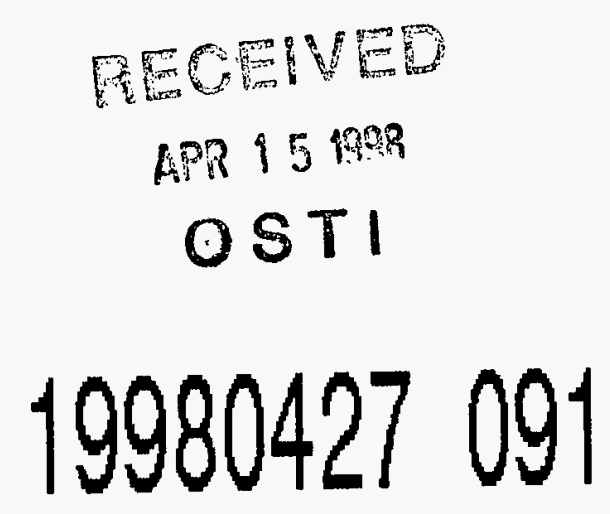

DISTRIBUTION OF THIS DOCUMENT IS UNLIMITED

\title{
MASTER
}

This document has been approved by the Y-12 Technical Information Office for release to the public. Date: 03/25/98

ENERGY SYSTEMS 


\section{ENTECH, Inc.}

contributed to the preparation of this document and should not be considered an eligible contractor for its review. 


\title{
Waste Management Plan for the Removal Action at the Former YS-860 Firing Ranges, Oak Ridge Y-12 Plant, Oak Ridge, Tennessee
}

Date Issued-March 1998

\author{
Prepared by \\ ENTECH, Inc. \\ Oak Ridge, Tennessee \\ under subcontract 1CK-AENO2V \\ Prepared for the \\ U.S. Department of Energy \\ Office of Environmental Management \\ under budget and reporting code EW 20 \\ Environmental Management Activities at \\ OAK RIDGE Y-12 PLANT \\ Oak Ridge, Tennessee 37831 \\ managed by \\ LOCKHEED MARTIN ENERGY SYSTEMS, INC. \\ for the \\ U.S. DEPARTMENT OF ENERGY \\ under contract DE-AC05-84OR21400
}




\section{DISCLAIMER}

This report was prepared as an account of work sponsored by an agency of the United States Government. Neither the United States Government nor any agency thereof, nor any of their employees, makes any warranty, express or implied, or assumes any legal liability or responsibility for the accuracy, completeness, or usefulness of any information, apparatus, product, or process disclosed, or represents that its use would not infringe privately owned rights. Reference berein to any specific commercial product, process, or service by trade name, trademark, manufacturer, or otherwise does not necessarily constitute or imply its endorsement, recommendation, or favoring by the United States Government or any agency thereof. The views and opinions of authors expressed herein do not necessarily state or reflect those of the United States Government or any agency thereof. 
CONTENTS

EXECUTIVE SUMMARY

v

1. INTRODUCTION

1.1 SITE LOCATION

1.2 SITE DESCRIPTION

2. OBJECTIVES

1

3. REMOVAL ACTIVITIES

.2

4. WASTE MANAGEMENT PLAN CHECKLIST

4.1 KEY PROJECT PERSONNEL

$\ldots 2$

4.2 WASTE GENERATION ACTIVITIES

.. 2

4.3 WASTE TREATMENT, STORAGE, AND DISPOSAL

3

4.4 WASTE TRANSPORTATION

3

5. HEALTH AND SAFETY

4

6. REFERENCES

4

APPENDIX. EMEF PROGRAM WASTE MANAGEMENT PLAN CHECKLIST

A-1

iii 


\section{EXECUTIVE SUMMARY}

This waste management plan defines the procedures for control and management of waste generated as a result of the removal action of the YS-860 Firing Ranges site at the Oak Ridge Y-12 Plant. This document includes plan objectives; remediation activities; key personnel; waste generation activities; and waste treatment, storage, transportation, and disposal. Methods of control and characterization of waste generated as a result of remediation activities will be within the guidelines and procedures outlines herein. ENTECH personnel will make every effort when conducting remediation and decontamination activites to minimize the amount of generated waste. 


\section{INTRODUCTION}

The Oak Ridge Y-12 Plant is currently under a Federal Facility Agreement to define soil and groundwater contamination and develop remedies to protect human health and the environment. This waste management plan addresses waste management requirements for waste generated during the remediation of the YS-860 Firing Ranges site at the Y-12 Plant. This document identifies the types and estimates the volumes of various wastes that may be generated during the proposed treatability studies. This approach to managing waste emphasizes the following:

- management of the waste generated in a manner that is protective of human health and the environment;

- minimization of waste generation, thereby reducing unnecessary costs and usage of limited permitted storage and disposal capacities; and

- compliance with federal, state, and site requirements.

\subsection{SITE LOCATION}

The YS-860 Firing Ranges are located at the east end of the Y-12 Plant complex, outside the Y-12 Plant fenceline near Scarboro Road. The Firing Ranges were used as a training facility for Y-12 Plant and the U.S. Department of Energy security forces. The smaller eastern range was used from 1943 until the mid-1950s. The larger western range was used until the mid-1980s. The site location is shown in Fig. 1 of the removal action work plan (DOE 1998).

\subsection{SITE DESCRIPTION}

The YS-860 Firing Ranges consist of the two firing range areas, the target embankments, and protective side berms. Sampling and analysis of the site has indicated that only the target embankments, the hillside directly behind the target areas, have elevated levels of lead contamination. The contaminated areas of the target embankments are $80 \mathrm{ft} \times 25 \mathrm{ft}$ and $200 \mathrm{ft} \times 45 \mathrm{ft}$ for the east and west embankments, respectively. A detailed site plan is shown in Fig. 2 of the removal action work plan (DOE 1998).

\section{OBJECTIVES}

The objective of the removal action is to excavate soil contaminated with lead bullets and shot and ship the contaminated soil to an off-site lead recycling and/or disposal company. The ultimate goal is to reduce the lead in the soil to levels below a risk-based clean-up level of $1400 \mu \mathrm{g} / \mathrm{g}$. 


\section{REMOVAL ACTIVITIES}

In 1996, a field investigation of the YS-860 Firing Ranges was conducted by Lockheed Martin Energy Systems, Inc. The investigation determined that elevated lead levels were present in the firing range target berm soils. The removal actions for lead source removal will include the following:

- removal of known lead-contaminated soil,

- removal of existing asphalt walkways and concrete trench slab,

- transportation of the concrete and asphalt debris to the Industrial Landfill V Spoil Area for disposal,

- verification sampling,

- $\quad$ site regrading, and

- shipment of contaminated soil to an off-site recycling and/or disposal facility in accordance with Resource Conservation and Recovery Act.

Site regrading will consist of ex́cavating the uncontaminated protective berms located on each side of the west firing range and using the soil to fill and recontour the site. The regraded site will be seeded and mulched. When the site is stabilized and the risk of soil erosion is minimized, the silt fence will be removed and disposed of in the $Y-12$ Construction Debris Landfill. The areas disturbed by the placement and removal of the silt fence will be repaired.

\section{WASTE MANAGEMENT PLAN CHECKLIST}

The strategies and methodologies to be used in the management of wastes generated during the removal action at the YS-860 Firing Ranges are documented in the Environmental Management and Enrichment Facilities (EMEF) Program Waste Management Plan checklist for the Y-12 Plant (see the appendix). The waste management plan checklist will be used in conjunction with site-specific waste management/waste certification plans and procedures to guide the handling and disposal of waste generated as part of project activities. The checklist provides guidance and recommendations to be used for ensuring the protection of the worker, the environment, and the public.

\subsection{KEY PROJECT PERSONNEL}

Individuals involved in the management of waste generated by this project include the project manager, EMEF Generator Interface, Facility Manager, Waste Coordinator, Site Remediation Contractor, Site Safety and Health Officer, and the EMEF Waste Management Coordinator. The names, addresses, and telephone numbers of these individuals are given in Sect. 1.0 of the checklist. 
The waste management responsibilities for these roles are described in the EO-710, ES-WM-10, and procedures identified in the checklist.

\subsection{WASTE GENERATION ACTIVITIES}

Activities associated with the remediation of the YS-860 Firing Ranges will result in the generation of solid wastes at the site. These activities are listed in Sect 3.0 of the checklist and are briefly discussed below.

- Site Clearing and Grubbing. Parts of the contaminated soil areas are vegetated with trees and shrubs. These areas will be cleared before soil removal. Trees, stumps, and roots that are substantially free from soil will be separated from the contaminated soil and handled as uncontaminated trees. Some trees, stumps, and roots will be burned after receiving the required burn permits, procured from Lockheed Martin Energy Systems, Inc.

- Contaminated Soil Removal. Soil contaminated with lead bullets and shot will be excavated and shipped to an off-site recycling and/or disposal facility. The contaminated areas have been identified during previous sampling and analysis activities, and the initial quantity of contaminated soil to be excavated will be approximately $660 \mathrm{yd}^{3}$. This material will be loaded into trucks or rail cars for shipment to the off-site recycling facility.

- Asphalt and Concrete Removal. Existing asphalt walkways and a concrete slab will be demolished and removed from the site. These materials will be handled as uncontaminated construction debris.

- Miscellaneous Waste. Used silt fence, plus a small quantity of miscellaneous waste, such as paper and trash, will be generated during remediation activities. These materials should be mostly uncontaminated and will be segregated and disposed of in a manner appropriate for each waste type.

\subsection{WASTE TREATMENT, STORAGE, AND DISPOSAL}

As documented in Sect. 7.1 of the checklist, the lead-contaminated soil will be shipped directly to a U.S. Department of Energy-approved and permitted off-site recycling and/or disposal facility. All other waste generated from field activities (identified in Sect. 4.0 of the checklist) will be transferred to the Waste Management Organization for disposal. Before transfer of waste to the Waste Management Organization, the appropriate waste management forms will be completed and signed. Section 7.3 of the checklist identifies the waste management forms that apply to the subject wastes. The waste certifier and the waste coordinator are responsible for completing and signing the forms. All waste to be transferred to the Waste Management Organization must be green-tagged by Radiological Control personnel

\subsection{WASTE TRANSPORTATION}

The remediation contractor will be responsible for transporting bulk waste to the disposal areas. Transportation will be coordinated with the Waste Management Organization. Expected routes of 
transportation are identified in Sect. 8.0 of the checklist. Waste generated will be transported in accordance with all applicable federal and state regulations, U.S. Department of Energy Orders, and Lockheed Martin Energy Systems, Inc., policies and procedures. All soil classified as Resource Conservation and Recovery Act hazardous will be transported under a hazardous waste manifest, approved and signed by Lockheed Martin Energy Systems, Inc.

\section{HEALTH AND SAFETY}

A project health and safety plan (ENTECH, Inc. 1998) has been developed using Lockheed Martin Energy Systems, Inc., standard practices when applicable. This plan describes all of the requirements to conduct project activities at the Y-12 Plant. It is the responsibility of the project managers, field managers, and site safety and health officers to ensure that this work is done safely. These personnel will verify that the health and safety plan is sufficiently protective. If it is determined that the requirements of the health and safety plan are not sufficiently protective, a field change order will be prepared. Field change orders will include a completed job hazard analysis or similar worksheet to ensure complete hazard assessment. Field change orders must be approved by the program manager, health and safety manager, subcontractor project or field manager, and subcontractor health and safety representative. As a minimum, field change orders will be prepared if additional tasks will be performed.

\section{REFERENCES}

DOE (U.S. Department of Energy) 1998. Removal Action Work Plan for the YS-860 Firing Ranges, Oak Ridge Y-12 plant, Oak Ridge, Tennessee, DOE/OR/01-1709\&D1, Lockheed Martin Energy Systems, Inc., Oak Ridge, Tenn.

ENTECH, Inc. 1998. Health and Safety Plan for the YS-860 Firing Range Removal Action, Oak Ridge, Tennessee, Y/ER-313, Lockheed Martin Energy Systems, Inc., Oak Ridge, Tenn. 


\section{APPENDIX}

\section{EMEF PROGRAM WASTE MANAGEMENT}

PLAN CHECKLIST 
A-3

\begin{tabular}{|l|l|}
\hline Original Issue Date: & \\
\hline Revision Date: & \\
\hline WMO \# (if applicable): & \\
\hline
\end{tabular}

\section{EMEF PROGRAM WASTE MANAGEMENT PLAN CHECKLIST}

\section{Removal Action at the Former YS-860 Firing Ranges PROJECT NAME}

\section{Y-12 Plant}

\section{ER WM PLAN CHECKLIST \#}

\begin{tabular}{|c|c|}
\hline ER Project Manager & Date $3 / 31 / 98$ \\
\hline Janice Hensley & \\
\hline ER Environmental Officer & Date $3 / 31 / 98$ \\
\hline Laura Feldman & Saura Jeldmar \\
\hline
\end{tabular}

\begin{tabular}{|c|c|}
\hline $\begin{array}{l}\text { ER Waste Management Certification } \\
\text { Official }\end{array}$ & Date $3 / 31 / 98$ \\
\hline Angela Fleming & Auaela Hemina \\
\hline Waste Management Organization & Date $3 / 31 / 98$ \\
\hline Mary Wiginton & $\mathrm{UV}_{\mathrm{i}}$ \\
\hline
\end{tabular}




\section{EMEF PROGRAM WASTE MANAGEMENT PLAN CHECKLIST}

\begin{tabular}{|l|l|l|l|}
\hline Project Name: & $\begin{array}{l}\text { Removal Action at the } \\
\text { Former YS-860 Firing Ranges }\end{array}$ & Est. End Date: & \\
\hline Location: & Y-12 Plant & $\begin{array}{l}\text { EMEF WM Plan } \\
\text { Checklist \#: }\end{array}$ & \\
\hline Est. Start Date: & & Charge \# for WM: & \\
\hline
\end{tabular}

\section{KEY PROJECT PERSONNEL}

\begin{tabular}{|l|l|l|l|}
\hline $\begin{array}{l}\text { ER Project } \\
\text { Manager: }\end{array}$ & Janice Hensley & ER Waste Certifier: & Angela Fleming \\
\hline Address: & $\begin{array}{l}\text { P.O. Box 2009 } \\
\text { Y-12 Plant Bldg. 9983-58 } \\
\text { MS-8247 }\end{array}$ & Address: & $\begin{array}{l}\text { Bldg. 9983-AH } \\
\text { MS-8247 }\end{array}$ \\
\hline Phone: & $574-2930$ & Phone: & 574-9551 \\
\hline
\end{tabular}

\begin{tabular}{|l|l|l|l|}
\hline Facility Manager: & N/A & Waste Generator: & Janice Hensley \\
\hline Address: & N/A & Address: & $\begin{array}{l}\text { P.O. Box 2009 } \\
\text { Y-12 Plant Bldg. } \\
9983-58 \\
\end{array}$ \\
& & & MS-8247 \\
\hline Phone: & N/A & Phone: & $574-2930$ \\
\hline
\end{tabular}

\begin{tabular}{|l|l|l|l|}
\hline Packager: & $\begin{array}{l}\text { ENTECH } \\
\text { Tim Long }\end{array}$ & $\begin{array}{l}\text { Site Health and } \\
\text { Safety officer: (if } \\
\text { applicable) }\end{array}$ & $\begin{array}{l}\text { ENTECH } \\
\text { Glen Cofer }\end{array}$ \\
\hline Address: & $\begin{array}{l}\text { 560 Oak Ridge Turnpike } \\
\text { Oak Ridge, TN 37830 }\end{array}$ & Address: & $\begin{array}{l}\text { 560 Oak Ridge } \\
\text { Turnpike } \\
\text { Oak Ridge, TN 37830 }\end{array}$ \\
\hline Phone: & $481-3231$ & Phone: & 481-3231 \\
\hline
\end{tabular}

\begin{tabular}{|l|l|l|l|}
\hline $\begin{array}{l}\text { ER Environmental } \\
\text { Officer: }\end{array}$ & Laura Feldman & $\begin{array}{l}\text { Waste Management } \\
\text { Organization }\end{array}$ & Mary Wiginton \\
\hline Address: & $\begin{array}{l}\text { Bldg. 9983-58 } \\
\text { MS-8247 }\end{array}$ & Address: & $\begin{array}{l}\text { Bldg. 9704-1 } \\
\text { MS 8060 }\end{array}$ \\
\hline Phone: & $241-4382$ & Phone: & $576-7768$ \\
\hline
\end{tabular}




\section{INTRODUCTION}

\subsection{PROJECT DESCRIPTION}

In 1996, a field investigation of the YS-860 Firing Ranges was conducted by Lockheed Martin Energy Systems, Inc. The investigation determined that elevated lead levels were present in the firing range target berm soils. The objective of the removal action is to excavate soil contaminated with lead bullets and shot and ship the contaminated soil to an off-site lead recycling and/or disposal company. The ultimate goal is to reduce the lead in the soil to levels below a risk-based clean-up level of $1400 \mathrm{ppm}(\mu \mathrm{g} / \mathrm{g})$.

The remedial actions for lead source removal will include the following:

- removal of known contaminated soil,

- removal of existing asphalt walkways and concrete slab,

- transportation of the concrete and asphalt debris to the Y-12 Plant landfill for disposal,

- verification sampling,

- site regrading, and

- shipment of contaminated soil to an off-site recycling and/or disposal facility in accordance with the Resource Conservation and Recovery Act.

\subsection{BRIEF SITE HISTORY}

The Firing Ranges were used as a training facility for Y-12 Plant and U.S. Department of Energy security forces. The smaller eastern range was used from 1943 until the mid-1950s. The larger western range was used until the mid-1980s. The YS-860 Firing Ranges are located at the east end of the Y-12 Plant complex, outside the Y-12 Plant fenceline near Scarboro Road.

\subsection{REFERENCE DOCUMENTS}

Y-12 Analytical Services Organization Official Report, Lockheed Martin Energy Systems, Inc., 1996.

Action Memorandum for Lead Source Removal at the Former YS-860 Firing Ranges, Y-12 Plant, Oak Ridge, Tennessee (YS-860 Memo), DOE/OR/02-1622\&D1 Jacobs EM Team, August, 1997. 


\section{WASTE GENERATION ACTIVITIES}

\begin{tabular}{|l|l|l|l|l|l|l|l|}
\hline & Coring & $\mathrm{X}$ & PPE & & Geophysical Survey & $\mathrm{X}$ & Remedial Actions \\
\hline & Drilling & $\mathrm{X}$ & Excavating & $\mathrm{X}$ & D \& D Activities & & UST Activities \\
\hline $\mathrm{X}$ & Deconning & & Renovating & & Well Installation/Maint. & & ISV \\
\hline & Water Sampling & $\mathrm{X}$ & Soil Sampling & & Scoping Surveys & $\mathrm{X}$ & Other: Tree Clearing \\
\hline
\end{tabular}

\section{Explain Other}

Part of the contaminated soil area is covered with small trees and shrubs. Before the excavation of contaminated soil, the trees and brush will be removed. The total area to be cleared is approximately $7600 \mathrm{ft}^{2}(1 / 6$ acre $)$. The trees will not be contaminated. Trees and shrubs will be burned after the proper permits are obtained and approved.

\subsection{WASTE GENERATING AREA}

East Fork Poplar Creek Watershed

\section{Location or Building Number(s)}

YS-860 Firing Ranges

\section{WASTE CHARACTERIZATION}

\subsection{WASTE TYPES AND VOLUME}

\begin{tabular}{|l|c|c|}
\hline Category & \multicolumn{1}{|c|}{$\begin{array}{c}\text { Sanitary Waste / } \\
\text { Industrial Waste }\end{array}$} & $\begin{array}{c}\text { Resource Conservation } \\
\text { and Recovery Act }\end{array}$ \\
\hline Type $^{2}$ & Solid & Solid \\
\hline $\begin{array}{l}\text { Description of Waste stream/ } \\
\text { Source }\end{array}$ & $\begin{array}{l}\text { Cleared trees }\left(500 \mathrm{ft}^{3}\right) ; \text { concrete } \\
\text { slabs and asphalt }\left(2700 \mathrm{ft}^{3}\right) ; \\
\text { personal protective equipment } \\
(\mathrm{PPE})\left(200 \mathrm{ft}^{3}\right) ; \text { plastic, misc. trash, } \\
\text { silt fence }\left(200 \mathrm{ft}^{3}\right)\end{array}$ & Lead-contaminated soil \\
\hline RAD - contact or remote handled & - & Lead \\
\hline $\begin{array}{l}\text { Suspected contaminants } \\
\text { (radiological and chemical) }\end{array}$ & - & - \\
\hline
\end{tabular}




\begin{tabular}{|c|c|c|}
\hline $\begin{array}{l}\text { Characterization of contaminant } \\
\text { by sampling and analysis (Yes/No) }\end{array}$ & yes, (previous sampling) & yes \\
\hline $\begin{array}{l}\text { Characterization of contaminant } \\
\text { determined by process knowledge }\end{array}$ & - & - \\
\hline Solids ${ }^{6}\left(\mathrm{ft}^{3}\right)$ & $3,600 \mathrm{ft}^{3}$ & $660 \mathrm{yd}^{3}$ \\
\hline Liquids $^{8}$ (gallons) & 1000 gallons & 0 \\
\hline $\begin{array}{l}\text { Volume that WMO may receive } \\
\text { (solids and liquids) }\end{array}$ & $\begin{array}{c}3,600 \mathrm{ft}^{3} \\
1000 \text { gallons }\end{array}$ & 0 \\
\hline $\begin{array}{l}\text { Volume that will be handled as } \\
\text { Investigation Derived Waste } \\
\text { (IDW) } \\
\text { (solids and liquids) }\end{array}$ & 0 & 0 \\
\hline IDW Type ${ }^{2}$ & $\mathrm{~N} / \mathrm{A}$ & N/A \\
\hline Destination $^{7}$ & Waste Management Organization & $\begin{array}{l}\text { To off-site permitted } \\
\text { disposal facility }\end{array}$ \\
\hline
\end{tabular}

RCRA, TSCA, LLLW, TRU, LLW/RCRA, LLW/TSCA, TRU/RCRA, TRU/TSCA, TRU/RCRA/TSCA,

LLW/RCRA/TSCA, RCRA/TSCA, sanitary waste/industrial waste, liquid waste to be treated at K-25 Site, liquid waste to be treated at ORNL, liquid waste to be treated at Y-12 Plant.

2 Liquid, sludge, solid, gas (compressed), etc.

Floor tiles, duct work, concrete, metal, plastic, soil, glass, cylinders, etc.

This not to include trace or naturally occuring chemicals or radionuclides found in nature.

Documents that defend process knowledge should be listed in Section 2.

See Methodology for Generating Waste Volumes Estimates (ORNL/ER-148). It is imperative that waste volumes be given the appropriate units. (i.e., solids in cubic feet, liquids in gallons, etc.)

Tumulus pads, waste treatment plant, SWSA 6, etc.

8 Liquids include water used for washing soil from heavy equipment, tools, and vehicles and cleaning solutions used during sampling equipment decontamination. Not expected to be RCRA hazardous, but sampling required.

What methodology was used to estimate waste volumes?

Calculations based on site plans site sampling. Assume excavation of soil to a depth of $1.25 \mathrm{ft}$.

\subsection{WASTE CHARACTERIZATION PLAN}

Waste has been characterized by a past investigation. Additional field verification sampling will be required.

Has the organization or person responsible for obtaining samples been designated?

\begin{tabular}{|l|l|l|l|l|l|}
\hline & Yes & $\mathrm{X}$ & No & & NA \\
\hline
\end{tabular}

List name (Remediation Contractor)

Date 
A-8

Has the organization responsible for analyzing samples been identified?

\begin{tabular}{|l|l|l|l|l|l|}
\hline & Yes & $\mathrm{X}$ & No & & NA \\
\hline
\end{tabular}

List name (Y-12 ASO Laboratory)

Date

Can Waste Management Organization (WMO) take control of the hazardous or mixed waste generated?

\begin{tabular}{|l|l|l|l|l|l|}
\hline & Yes & $\mathrm{X}$ & No & & $\mathrm{NA}$ \\
\hline
\end{tabular}

Person Contacted Mary Wiginton

Date

Can Waste Management Organization (WMO) Accept the volume of radiological waste to be generated?

\begin{tabular}{|l|l|l|l|l|l|}
\hline & Yes & & No & $\mathrm{X}$ & NA \\
\hline
\end{tabular}

Person Contacted

Date

Can the WMO accept the liquid that will be generated?

\begin{tabular}{|l|l|l|l|l|l|}
\hline$X$ & Yes & & No & & NA \\
\hline
\end{tabular}

Person Contacted Angela Fleming Date

Will TRU or mixed waste be generated?

\begin{tabular}{|l|l|l|l|l|l|}
\hline & Yes & $\mathrm{X}$ & No & & NA \\
\hline
\end{tabular}

If any TRU or TRU Mixed Waste is to be generated, contact the Waste Certification Official before project starts.

Person Contacted N/A Date

Will any of the waste generated be handled as IDW?

\begin{tabular}{|l|l|l|l|l|l|}
\hline & Yes & $\mathrm{X}$ & No & & NA \\
\hline
\end{tabular}


List any specific requirements as required by any of the above organizations or compliance.

Waste Acceptance Criteria for Oak Ridge Reservation, ES/WM-10; Waste Certification Requirements for Energy Systems, EP-710; Environmental Restoration and Waste Management Organization Waste Certification, EMEF/EM-P2109; Procedure Y-70-903;

Transfer of Waste to Y-12 ESWMO; Procedure Y-70-301; Waste Container Labeling

Who will be responsible for completing the weekly ER Waste Management Program Total Waste Generated Waste form?

Name: Angela Fleming Date

\section{HANDLING AND STORAGE REQUIREMENTS}

\subsection{LIST SPECIAL HANDLING PROCEDURES FOR WASTE OR WASTE CONTAINERS}

\subsection{LIST WHAT WILL BE USED TO PROTECT THE INTEGRITY OF WASTE CONTAINERS FROM ENVIRONMENTAL ELEMENTS. (EXAMPLES: LID TOPS, PLASTIC COVERING, EPOXY, STORAGE SHELTER)}

\subsection{APPLICABLE WASTE STORAGE AREA(S)}

\begin{tabular}{|l|l|l|l|l|l|l|}
\hline & Waste Staging Area & & Satellite Accumulation Area & & \multicolumn{2}{|l|}{ Waste Consolidation Area } \\
\hline & 90-d Storage Facility & X & Area of Contamination & & Other: & \\
\hline
\end{tabular}

\section{Describe location of above areas (attach Sketch)}

The location of waste staging area for Sanitary Waste/Industrial Waste will be determined in cooperation with Waste Management Organization and the EMEF Waste Management Manager before the start of the project. The temporary staging area will be located near the decontamination area which will be designated by the EMEF Waste Management manager. Contaminated soil will be directly loaded into the lined, tarp-covered trucks by the excavation equipment for immediate shipment to the off-site permitted disposal facility and therefore will not require a waste staging area. 


\subsection{EXPLAIN HOW WASTE WILL BE MANAGED TO ASSURE THAT PERSONAL SAFETY AND ENVIRONMENT WILL BE PROTECTED.}

ENTECH to perform work in accordance with approved plan.

Name of EMEF Waste Storage Area Supervisor:

Does supervisor and staff have the appropriate training?

\begin{tabular}{|l|l|l|l|l|l|}
\hline $\mathrm{X}$ & Yes & & No & & NA \\
\hline
\end{tabular}

\section{List training requirements:}

General Employee Training (GET), Storm Water Pollution Prevention (Module \#16987)

Will a spill control kit be required on-site?

\begin{tabular}{|l|l|l|l|l|l|}
\hline $\mathrm{X}$ & Yes & & No & & NA \\
\hline
\end{tabular}

\section{List items:}

Absorbent materials, plastic sheeting, Tyvek, gloves, absorbent pads or pillows.

\section{WASTE MINIMIZATION}

\subsection{WASTE MINIMIZATION TECHNIQUES TO BE IMPLEMENTED}

\begin{tabular}{|l|l|r|l|}
\hline $\mathbf{X}$ & Segregation & & IDW Concept \\
\hline $\mathbf{X}$ & Decontamination & & Material Recycle (Solvents, Decon Waters) \\
\hline & Compaction & & Cutting Fluids Recovery \\
\hline & Solvent Substitution & & Selection of Equipment \\
\hline & Sludge Dewatering & & Solidification \\
\hline & Selection of PPE & $\mathbf{X}$ & Other \\
\hline
\end{tabular}

Explain specific techniques not listed above. Sampling equipment will be decontaminated between composite samples, not individual sampling locations. Cleaning of precleaned heavy equipment, tools, and vehicles will, be limited to washing soil from the equipment before leaving the site. 


\section{TREATMENT, STORAGE, AND DISPOSAL OPTIONS}

\subsection{POTENTIAL TREATMENT STORAGE OR DISPOSAL OPTIONS (IF APPLICABLE)}

\begin{tabular}{|l|l|c|}
\hline \multicolumn{1}{|c|}{ Option } & \multicolumn{1}{|c|}{ Waste Capacity } & Responsible Organization \\
\hline Treatment & Lead contaminated soil: $660 \mathrm{yd}^{3}$ & ENTECH \\
\hline Disposal & $\begin{array}{l}\text { Concrete slabs, asphalt, cleared trees, PPE, } \\
\text { sanitary waste, silt fence: } 3,600 \mathrm{ft}^{3}\end{array}$ & $\begin{array}{c}\text { Waste Management } \\
\text { Organization }\end{array}$ \\
\hline Disposal & Decontamination Fluids: $1000 \mathrm{gal}$ & $\begin{array}{c}\text { Waste Management } \\
\text { Organization }\end{array}$ \\
\hline
\end{tabular}

\subsection{SPECIAL REQUIREMENTS OF THE WASTE ACCEPTANCE CRITERIA TO MEET}

Waste Acceptance Criteria (WAC) for off-site disposal facility

- Minimal moisture content is acceptable, but no free liquid

- Total organic compounds (TOCs) must not exceed 500 ppm

- Certification or evidence that the material is free of radioactive constituents

- Soil analysis for heavy metal content [not toxicity characteristics leaching procedure (TCLP)]

- TCLP for arsenic, barium, cadmium, chromium, lead, mercury, selenium, and silver

- Soil pH

- Soil particle size distribution

- Analysis for volatile organic compounds (VOC), semi volatile organic compounds (SVOC), polychlorinated biphenyls (PCBs), pesticides and herbicides

WAC for Landfill Spoil Área

- Green Health Physics tag

- Concrete and asphalt only

WAC for Burn Yard (for trees and brush)

- Green Health Physics tag

- Soil removed

- No drums 
7.3 APPLICABLE WASTE MANAGEMENT FORMS:*

\begin{tabular}{|l|l|l|l|l|l|l|l|}
\hline & UCN-2822 & & UCN-1457 & X & UCN-2109 & & TX-5352A \\
\hline & UCN-16114 & X & UCN-20-116 & & UCN-20117 & & Other \\
\hline & UCN-16114A & X & UCN-19611 & X & UCN-20118 & & \\
\hline
\end{tabular}

*List Person(s) that will be responsible for completing and signing Waste Management form(s):

Waste Certifier, Waste Coordinator

\section{TRANSPORTATION}

\subsection{TRANSPORTATION REQUIREMENTS}

A. Who or what organization will transport waste to the WMO facility?

Waste Management Organization

B. List specific issues for transporting waste and their resolutions.

Waste Management Organization will provide transportation to the waste staging area. All applicable federal and state regulations, U.S. Department of Energy orders, and Lockheed Martin Environmental Restoration LMER/LMES policies and procedures will be adhered to when transporting waste.

Approved hauling contractors to off-site disposal facilities. An LMES/DOE-approved carrier will be used to transport waste off-site. All applicable federal and state regulations, permits, DOE orders, and Lockheed Martin Environmental Restoration LMES/LMER policies and procedures will be adhered to before transporting waste off-site.

\section{SAFETY AND HEALTH PLAN}

\subsection{LIST NAME OF APPROPRIATE ENVIRONMENTAL SAFETY \& HEALTH DOCUMENTATION ASSOCIATED WITH THIS PROJECT}

Health and Safety Plan for the YS-860 Firing Ranges Removal Action 
9.2 NAME OF THE PLAN

Removal Action Work Plan for the YS-860 Firing Ranges

9.3 Date Approved or Expected date of approval

10. Additional Information to Further Define Waste Management Activities 


\section{DISTRIBUTION}

1. C. S. Haase

2. J. F. Hensely

3. P. T. Owen

4. L. B. Raulston

5. V. L. Turner

6. File-EMEF DMC-RC

7. R. Adkisson, ENTECH, Inc., 560 Oak Ridge Turnpike, Suite 2, Oak Ridge, TN 37830

8. M. Allen, Bechtel Jacobs Company LLC, 151 Lafayette Dr., Oak Ridge, TN 37830 


\section{M98004546 \\ |||||||||||||||||||||||||||||||||||||||||||||||}

Report Number (14)Y/ER - 3/5

Publ. Date (11) 199803

Sponsor Code (18) DOElEM; DOE/DP,XF UC Category (19) UC-2000;UC-702, DOEIER 